\title{
THE DYNAMICS TRANSFORMATION OF LIVING MEDIA CONSUMPTION IN THE DIGITAL ERA (SHIFTING PREFERENCES STUDY FROM MEDIATED MEDIA EDITORS TO UNMEDIATED MEDIA EDITORS AND TO MEDIATED MEDIA EDITORS)
}

\author{
Yeremia Angga Sugiyanto ${ }^{1}$, Firman Kurniawan ${ }^{2}$ \\ ${ }^{1,2}$ Communication Studies Department / Social and Political Science Faculty Universitas Indonesia \\ Email: jerryarvino@gmail.com
}

\begin{abstract}
ABSTRAK
Pada perkembangan teknologi saat ini memiliki perubahan yang sangat signifikan khususnya dalam dunia media massa. Digitalisasi yang terus berkembang pesat ini mempengaruhi komunikasi masa yang memiliki cakupan luas sehingga dapat menghubungkan kepada khalayak secara cepat. Salah satu pergeseran paradigma yang terjadi yaitu dari editormediated ke non-editor mediated. Hal ini menjadikan pergeseran ini sebagai salah satu dampak dari perkembangan teknologi yang penting untuk dikaji. Dengan perkembangan tersebut khalayak memiliki peran besar dalam memperoleh informasi dan membuat berbagai pilihan informasi yang ingin didapatkan. Penelitian ini bertujuan untuk mengetahui dinamika transformasi konsumsi media dari editor-mediated ke non-editor mediated. Dalam penelitian ini menggunakan teori User and Gratification untuk melihat peran aktif dalam proses komunikasi dalam memenuhi kebutuhannya. Adapun pendekatan dan metode penelitian ini menggunakan pendekatan kualitaif dengan metode fenomenologi untuk melihat saling berpengaruhnya satu peristiwa dengan situasi tertentu. Hasil dalam penelitian ini pada era digital ini konsumen atau pembaca berita beralih menjadi pengguna yang lebih aktif dalam melakukan diskusi dan mengemukakan aspirasinya. Hal ini menghasilkan paradigm baru media dengan dari editor-mediated menjadi non-editor mediated sehingga dalam penelitian yang dilakukan ini perkembangan teknologi turut mempengaruhi dan dapat membantu khalayak dalam memperoleh informasi. Dalam preferensi ini faktor trust merupakan kunci dari kredebilitas suatu media untuk menjaga kualitas konten dan layanan yang diberikan sehingga khalayak akan menumbuhkan harapan yang baik untuk dimasa yang akan datang.
\end{abstract}

Kata Kunci: Editor-Mediated, Non-Editor Mediated, Trust, Digitalisasi, Media

\section{THE DYNAMICS TRANSFORMATION OF LIVING MEDIA CONSUMPTION IN THE DIGITAL ERA (SHIFTING PREFERENCES STUDY FROM MEDIATED MEDIA EDITORS TO UNMEDIATED MEDIA EDITORS AND TO MEDIATED MEDIA EDITORS)}

\begin{abstract}
Nowadays technology development has very significant changes, especially in the world of mass media. This rapidly growing digitalization has affected mass communication which has a broad scope so that it can connect to audiences quickly. One of the paradigm shifts that occurs is from editor-mediated to non-editor-mediated. This makes this shift one of the impacts of technological developments that is important to study. With this development, the audience has a big role in obtaining information and making various choices of information that they want to get. This study aims to determine the dynamics of the transformation of media consumption from editor-mediated to non-editor-mediated. In this study using the theory of User and Gratification to see an active role in the communication process in meeting their needs. The approach and method of this research use a qualitative approach with a phenomenological method to see the influence of one event with a certain situation. The results of this study in this digital era that consumers or newsreaders turn to be users who are more active in conducting discussions and expressing their aspirations. This results in a new paradigm of media from editor-mediated to non-editor mediated so that in this research, technological developments also influence and can help audiences in obtaining information. In this preference, the factor trust is the key to the credibility of a media to maintain the quality of the content and services provided so that the audience will raise good hopes for the future.
\end{abstract}

Keywords: Editor-Mediated, Non-Editor Mediated, Trust, Digitalization, Media

Publish by Communication Science Program, Social Politic Faculty Universitas Muhammadiyah Buton. 
Korespondensi: Yeremia Angga Sugiyanto. Communication Studies Department / Social and Political Science Faculty Universitas Indonesia. Alamat: Jl. Margonda Raya, Pondok Cina, Kecamatan Beji, Kota Depok, Jawa Barat 16424. No. WhatsApp: Email: jerryarvino@gmail.com

\section{INTRODUCTION}

The era of the Industrial Revolution 4.0 has changed the face of the mass media. The digitalization of media in the form of an internet connection has made the social life order in society change, including in the matter of obtaining and consuming information. The digital revolution has changed people's behavior and culture in communicating and consuming news. From conventional media or print media, which used to be the most influential media in the distribution of information throughout the world, it has now changed to digital / online media with the rapid growth of the internet and its networks (Sucahya, 2013). The phenomenon of stagnation to the global decline of conventional media in the form of print media and newspapers has occurred in Europe and America since 2009, and has been increasingly evident in Indonesia from 2015 to 2017. This can be seen from the partial or total closure of a large amount of print media even from large media groups. PwC's business consultant in the Perspective from the Global Entertainment and Media Outlook 2017 report stated that the global rate of newspaper growth in the next five years (until 2022) is minus 8.3\%. This is the lowest figure because the prediction for other conventional mass media (magazines, radio, television and books) is minus $3.4-6 \%$ only. On the other hand, $\mathrm{PwC}$ predicts internet-based media to grow by 0.5 to $6 \%$.

According to Data from the Indonesian Internet Service Providers Association (APJII), it also shows an increase in the number of internet users in Indonesia. In the last 15 years (2002 - 2017) there has been an increase in internet access from 4.5 million netizens to 145 million netizens. Meanwhile, from the results of data presented by the Reuters Institute, $51 \%$ of respondents admitted to using social media as a source of news. News portals are no longer considered their main source of information, with $12 \%$ of respondents stating that social media is their main source of news. Data from the same source revealed that $28 \%$ of young people aged 18-24 years rely on social media as the main place to get news compared to conventional media such as television or newspapers.

Apart from social media, news aggregator applications are also growing quite rapidly as a place for people to get news. This is what changes a person's behavior in obtaining information (Kusuma, 2016). According to the Reuters Institute, $36 \%$ of respondents admitted to reading the news because it was automatically recommended by the machines working behind the platform. Reportedly, this method produces a higher percentage of newsreaders than content recommended by journalists or editors. The content of the news aggregator is moderated and comes from trusted sources. Besides, the artificial intelligence technology behind the news aggregator platform will send information based on the interests or preferences of the audience (Asyir \& Nurbaya, 2019). And according to the theory of Uses and Gratification, there are reasons about what hopes or searches underlie audiences to access the media, and the extent to which the audience 
can fulfill their expectations and searches. In this context the audience is considered an active agency that already has good media literacy, and understands the expected expectations and satisfaction.

The era of media digitization that spreads globally and is also supported by the results of a survey conducted by the Pew Project For Excellence in Journalism in 2010 stated that 4\% of respondents read news online in $1 \times 24$ hours (31\% chose to read through newspapers) and overall at the time, $41 \%$ read through online media and 10\% read through newspapers. Of the 18-29 year olds, $65 \%$ said their main source of news was the internet.

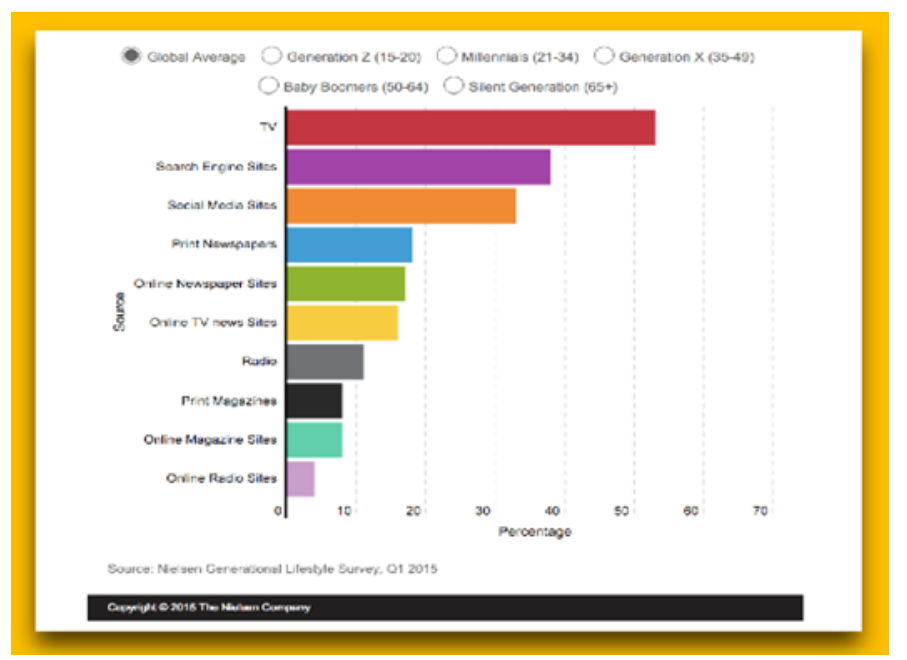

Figure 1: Information Consuming Preferences

(Source: Nielsen, 2015)

The results of research from Nielsen, in the Nielsen Generation Lifestyle Survey 2015, also illustrate facts that show a shift in preferences in consuming information. This presents challenges to conventional media such as: audience relations (interactivity), new languages (multimedia), and new structures or words (hypertext). This media revolution not only changed the communication landscape but also opened a mass communication system with a wider scope (Orihuela, 2017).

In his journal entitled eCommunication: The 10 Paradigms of Media in the Digital Age, Orihuela describes the shift in media paradigm in the digital era. One of the paradigm shifts that occurs is from editormediated to non-mediated. Initially, the role of processing and providing information was usually one-sided and started with the media concerned in defining everyday issues. This shift phenomenon appears to be seen and occurs as a result of the development of the internet, which makes other informal sources of information (apart from conventional media) relevant to everyday issues. This opens up opportunities for the public to have a bigger and wider role to participate in being a source of information production (Aminuddin \& Hasfi, 2020). They can also comment on the news or information and choose information sources more diverse. The 
speed of coverage is also an advantage factor that makes audiences choose to switch to social media rather than through conventional media.

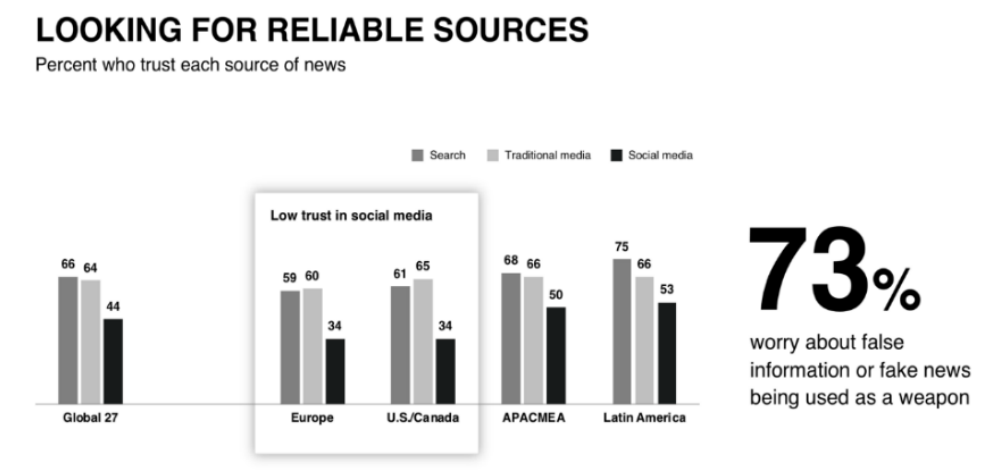

Figure 2 : Edelman Trust Barometer 2019

(Source: Edelman.com, 2019)

But on the other hand, a survey conducted by Edelman Trust Barometer (2019) also explains the low trust in social media, $73 \%$ of them are even worried about the validity of the information they receive because it is often ridden with the interests and agenda-setting of the informants concerned. The same survey also explains the impact on the level of trust in traditional / conventional media which remains high, even surpassing other online media and social media. In addition, with the flood of information that can be produced, distributed and consumed by everyone as well as the waves of hoaxes, fake news and the accompanying disinformation, there has been a shift back from the way people consume media, from nonmediated (when information is produced and distributed by the audience) to editors. mediated (when information is produced by conventional media that is more credible and adheres to the values and discipline of journalism to produce and guarantee the quality of reliable information. As quoted by a statement from Rusadi (Rusadi, 2014) observers of culture and digital communication in an interview with Media Indonesia, Information that can be accessed by everyone, as currently, is a turning point for the public to return to conventional media because audiences are becoming very critical and selective about the information they consume, and making the credibility of information sources an important consideration.

The problems that occur in this digitalization era have changed people's behavior in communicating and consuming news. From a mediated editor (which is under a certain organization) to non-mediated (when information is produced by the public) (Respati, 2014). In recent developments, a shift in preference has occurred again to editor-mediated (when information is produced by a media that is more credible and adheres to the values and discipline of journalism). This is all done to produce and guarantee the quality of reliable information, to reduce disinformation along with the flood of information, hoaxes and fake news that accompany it. This makes researchers want to analyze how and why there is a dynamic process of transforming media consumption among audiences who experience shifts, even reversals, of media consumption patterns. The audience, who previously switched from Mediated Media Editor to Non-Mediated Media which is faster, and has various points of view, instead chose to shift back to Mediated Media Editor. 
For these problems, this study uses the main concept of Uses and Gratification to be able to answer the problems that occur. The concept of Uses and Gratification states that media users play an active role in selecting and using media (Kania et al., 2011). In other words, media users are active in the communication process. Media users try to find the best media sources to meet their needs (Alsridi, 2018). According to the opinion of this theory, media consumers have the freedom to decide how they use media and how the media will impact themselves (Nurudin, 2007: 192). Thus, the essence of the Uses and Gratification theory is that the audience basically uses mass media based on certain motives. If this motive is fulfilled then the needs of the audience will be fulfilled. In the end, the media that able to meet the needs of the audience is called effective media (Kriyantono, 2009: 206). Thus, for the problems that occur, this study aims to determine the dynamics of the transformation of media consumption which is characterized by editor-mediated to nonmediated so that researchers can find out media consumption patterns that tend to shift back from nonmediated to editor-mediated in the era of development digital today.

\section{RESEARCH METHODS}

This study uses a constructivist paradigm because the researcher examines the process of interaction between individuals which also focuses on the specific context in which people live and work, to understand the historical and cultural settings of the informants. Researchers admit that their backgrounds can shape their respective interpretations. In addition, they position themselves in research to acknowledge how their interpretations flow from their personal, cultural, and historical experiences. In constructivists, the researcher intends to understand or interpret the meaning that other people have about the world. Therefore, instead of starting with a theory (as in post positivism), researchers generate or inductively develop theories or patterns of meaning (Creswell, 2014).

This study uses a qualitative approach by exploring and understanding the meaning of individuals or groups related to social or human problems (Creswell, 2014). Thus, researchers try to understand and interpret phenomena in terms of the meanings that other people bring to them (Ritchie \& Lewis, 2003). The descriptive description is carried out to describe or describe a phenomenon systematically as it is to find information about the current state and try to describe the real situation according to the formulation of the problem posed (Dantes, 2012: 51).

Data collection in this study is in the form of interviews and the collection of literature documents/literature reviews - both online and offline - related to the research topic. The type of interview used is a structured interview, so that the information received can be described clearly. In addition to placing the results of interviews as primary data, the authors also use literature documents as a reference for secondary data and complement the main data. Data collection techniques in communication research include: questionnaire, interview, observation (observation), documentation and field experience notes (Pujileksono, 2015). In this study, the source of evidence used in data collection was by conducting interviews with 
informants who matched the criteria for the selected informants. To accommodate related information needs, researchers will conduct in-depth interviews where interviews will be conducted openly and unstructured but planned with a list of questions as appropriate in the survey interview as a guide.

\section{RESULTS AND DISCUSSIONS}

Based on the Uses and Gratification theory, there are differences in media consumption preferences which are also influenced by differences in the needs of each individual as an active audience, including cognitive needs that trigger curiosity to continue to dig up information until satisfied (Omar, 2014). The decision of media consumers to use their activeness in consuming media is also based on their preference for a particular topic and discussion. According to Vander (2020) that there are other reasons for consuming media, usually based on continued dissatisfaction with looking for other media that suits his curiosity, following the characteristics, especially for 'eccentric' things that are rarely discussed by traditional media in general. Then, the search for a new and different perspective or point of view also influences.

In the Uses and Gratification theory model, there are also social environmental factors that determine the needs of the audience. One of them is illustrated by demographic characteristics, namely that generation differences are considered to be able to affect a person's preference for information consumption (Musa et al., 2016). Generational differences can influence a person in fact-checking and critical thinking processes in processing information that is carried out when consuming media, which is validated by research conducted by Roy Morgan, an Australian business research office in the following table;

Indonesia's Top News websites by Generation - 12 months to March 2018

\begin{tabular}{llll}
\multicolumn{1}{c}{$\begin{array}{c}\text { Baby Boomers } \\
(1946-1960)\end{array}$} & \multicolumn{1}{c}{$\begin{array}{c}\text { Generation X } \\
(1961-1975)\end{array}$} & $\begin{array}{c}\text { Generation Y } \\
(1976-1990)\end{array}$ & \multicolumn{1}{c}{$\begin{array}{c}\text { Generation Z } \\
(1991-2005)\end{array}$} \\
\hline 1 KOMPAS.com & detikcom & detikcom & detikcom \\
\hline 2 detikcom & KOMPAS.com & KOMPAS.com & KOMPAS.com \\
\hline 3 Tribunnews.com & LIPUTAN6 & LIPUTAN6 & LIPUTAN6 \\
\hline SINDONEWS.com & JawaPos.com & Tribunnews.com & Tribunnews.com \\
5 TEMPO.CO & Tribunnews.com & JawaPos.com & JawaPos.com \\
\hline
\end{tabular}

Source: Roy Morgan Single Source Indonesia: April 2017 - March 2018, n = 30,311 Indonesians aged 14+.

Figure 3 : The consumption of media via website from different generation (Source: Generation, 2018)

Based on the results of research by Roy Morgan, it also shows differences in the preferences of media choices consumed by audiences between generations. A person's preference in consuming information can also be influenced by social relationships and interactions with their social environment. There is a tendency for the generation of parents to disseminate information on their environment, so that it is seen as more up-todate about knowledge and insight than the surroundings, although the news that is distributed is not necessarily valid (Haqqu, 2020). However, researchers found that online media currently has a major influence and plays 
a major role in determining consumer decisions regarding media consumption preferences. This is according to the results of an interview conducted with Vander:

"Like e-KTP corruption case in 2017, Setya Novanto, he got reviewed 2 episodes like that. And there is not enough ... one what is the name, one magazine, it will be published again next week. So the news is got continued. So when I read it, wow, it's really valid. It turns out that there is real evidence that all the reporters left for the US " (Result of the interview with Vander, 2020).

This preference will influence the audience to choose the media for consumption. Responding to an active audience in their search for the fulfillment of information needs, the mass media competes with other sources to compete for internal attention for media consumers (Gushevinalti et al., 2020). This competition leads to various ways to differentiate between media. Realizing the audience's need for speed, various media are also competing to satisfy the needs of audiences for information searches such as the Tempo media, which increases public trust by looking for information directly abroad to obtain valid and reliable information for the public.

Apart from that, in the mass media business, they are also competing to get information quickly. This was said by Bambang, an editor in chief of Tempo magazine, who said that:

"Apparently they are just competing in there, between Detik, Kumparan, and Tempo.co, Who gets the information first, they can immediately verify. who gets the name of the victim first, who gets information about another victim, where is the family comes from, where is the hospital? So that was the follow-up of the $3 \mathrm{~W}$ and makes all information complete. "(Interview with Mr. Bambang, 2020).

This will certainly affect the perspective of the audience in fulfilling their needs as an information medium in Indonesia. Because people want to get information quickly in this digital era. Detikcom is breaking the mainstream pattern by offering speed of coverage in the era of globalization and following the audience's need for fast information. This creates an awareness of the importance of speed so that readers can feel the most updated compared to others.

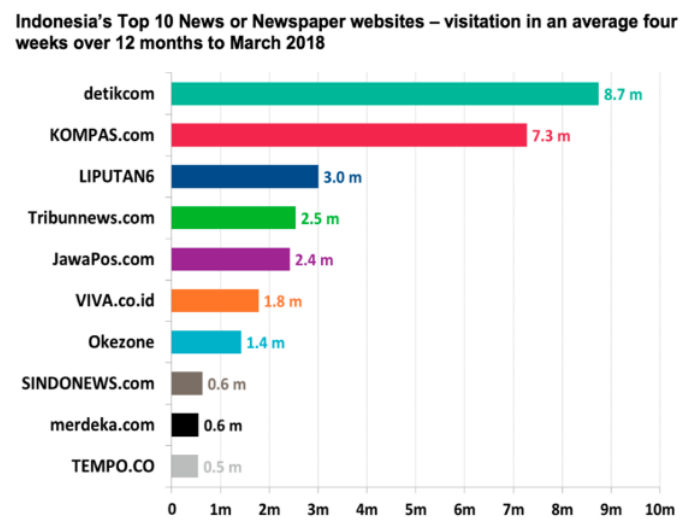

Figure 4 : Roy Morgan Single Source Indonesia: April 2017 - March 2018, n = 30,311 Indonesians aged 14+ (Source Indonesia, April 2017 - March 2018, n = 30,311 Indonesians aged 14+)

The speed of information presented by Detikcom reaped positive results in attracting the attention of audiences, especially media consumers. Quoting from roymorgan.com, an Australian business research office, Detikcom is clearly the most popular news site or newspaper in Indonesia which is accessed by more than 8.7 million Indonesians in an average period of four weeks, well above its closest competitor KOMPAS. com with nearly 7.3 million visitors and was ranked third in LIPUTAN6 with 3 million visitors. But KOMPAS.com 
is leading the way in rural Indonesia. detikcom dominates all major demographics as the leading news site for both sexes, for Indonesian youth including Generation X, Generation Y, and Generation Z, and in the largest urban area in Indonesia.

This result can be seen with evidence of public confidence in choosing sources of information media in Indonesia. More than 20 million people choose Detikcom from 4.2 million visitors in an average of four weeks, almost double compare to KOMPAS.com with more than 2.2 million visitors. But in smaller urban areas the two are more evenly matched with detikcom with an average of 1.82 million visitors in four weeks ahead of KOMPAS.com with 1.78 million visitors. In rural Indonesia area, KOMPAS.com with an average of more than 2.3 million visitors in four weeks is the most visited news site after detikcom with 1.8 million visitors and JawaPos.com with 1.4 million visitors. Thus, in gaining the trust to obtain information for the public, there are various views of its own so that the audience can determine the information obtained in using and accessing information according to their needs.

\section{Paradigm in Non Mediated Media Consumption}

The media revolution has changed the pattern of media consumption and resulted in a new media paradigm. Digitalization in the form of internet technology is the biggest trigger for this shift, where there is a phenomenon of the importance of the speed of information or news. As through Pak Bambang's illustration, by illustrating the importance of speed in the business world, for example, brokers or anyone who plays stocks will be facilitated to make decisions at the speed of information they have, when other people do not have that information. What is called by Joseph Stiglitz as a asymmetric information, where there is unequal access to information owned by the audience, which affects many things.

The speed in today's development is also the embryo of birth for Non-Mediated Media, where the information produced is no longer mediated by professional editors and opens up great opportunities for online journalism, when the audience is not only consumers, but can also produce information or news. NonMediated Media also allows reciprocal two-way communication by opening up discussion spaces to express the aspirations and perceptions of the audience through social media and other media. This is reinforced by the fact that Non-Mediated is one of the main accesses in turning information into news according to the results of an interview with Bambang:

"Accessibility especially what I said earlier about What Where When (3W), maybe social media is much faster than conventional media because it is tweeted by eyewitnesses very often. For example, When people see car accidents or collisions, they take photos, they upload them into social media. On the other hand, sometimes the Journalists are in different places not exactly in the accident scene. So reporters have to follow that evidence, see if it's true or not, then they just send people to verify, checking back and forth. Back then when "Why and How" are getting questioned, usually people who tweets are having an intention to asking questions intensively to get the information, they take pictures, saw it and if it matches, the reporters will start writing the news based on that tweet. Within a minute, they could find "What and When", then "Where" by checking clearly is it the fact or not." (Result of an interview with Mr. Bambang, 2020) 
This shows that the large amount of information generated by social media is since there are so many news producers in the form of online journalism through citizen journalism, making Mediated Media Editor journalists relatively less fast in reporting to the public. This requires journalists to be able to explain further the reasons why and how an incident or event occurs, while still guided by the audience's need for information or news that is time sensitive and has news value.

On the other hand, in responding to the phenomenon of Editors Mediated Media versus Non-Mediated Media, social media (Non Mediated) can help conventional media businesses (Editor Mediated) because it can generate more curiosity in the public to continue to explore more information than what is offered by Non Mediated speed, especially in terms of why and how which explains the situation and reasons for an event.

\section{Non-Mediated Media vs Mediated Media}

The presence of Non-Mediated Media as an alternative to consuming information that offers speed news is highly appreciated. However, interest in the speed of information is slowly being eroded along with the flood of informations that overload, so the audience is actually annoyed. Vander also explained his interest in the speed of information before finally feeling annoyed and turning back to the Mediated Editor, it happened because of the large amount of information that eventually created bias and multiple interpretations, causing discomfort from media consumers. Besides, according to him, fast news is usually not accompanied by the completeness and depth of information required.

Based on the results of this study, the audience tends to return to the Mediated Editor who applies journalism ethics and verification discipline. This is supported by researchers because the speed offered by Non Editors of Mediated Media has a tendency to be biased, so that they feel they need more quality of information that journalism offered by Mediated Media Editor. This is consistent with the statement from Vander and Bambang that:

"Yes, I definitely prefer quality than speed. Whereat least I know $5 \mathrm{~W}+1 \mathrm{H}$. When we compared it to something like fast information, but it comes biased. For example, some news might be just writing that only $2 W$, and questioning where is the other $3 W$. I prefer to read long but clear, detailed, and depth. " (Results of interviews with Mr. Bambang and Vander, 2020).

This will relate to the level of trust for the public in a media which is often influenced by several factors, including the length of existence of the media, which shows the credibility and validity of the media that has been trusted for a long time and can also be influenced by the figure behind it (the media). The reputation that is built from media that has long existence in businesses shows that the media has credibility because it can maintain its content properly, with quality and trustworthy. The quality means is also because the media is not touched by hoaxes in the midst of the flood of information that has occurred, causing trust in the public. The integrity and character of a media are also important factors that influence media consumption preferences in fostering trust because consumers feel represented by their voices on the media.

Trust is a very important factor in the preferences of media consumption by the public. Which media that they might be chosen. As a way to get the trust of the public, credibility is needed and became very 
important for the audience as a reference to fulfilling their satisfaction in consuming information. The credibility referred to in this research is adherence to journalistic ethics. In Indonesia, there are three things related to journalistic ethics that serve as guidelines or guidelines for the media and all journalism activities, namely the Press Law No. 40/1999, Journalistic Code of Ethics, and CyberMedia Coverage Guidelines. Thus, in gaining the trust of audiences various factors are ranging from increasing trust for audiences, and how the media influences audiences to gain existence and showing credibility for the needs of audiences. This is very important considering that audiences have media preferences according to their own perspectives and needs.

\section{CONCLUSION}

Along with the growth of digital era, there has been a media revolution with the presence of the internet which allows the public not only to act as media consumers but also to participate in news production behavior in the form of citizen journalism. The preference for media consumption by the public certainly has an important role in this shifting phenomenon which results in a new media paradigm and changes the pattern of media consumption by the audience from a Mediated Editor to a Non-Mediated Editor. In this era of nonmediated media, there is the phenomenon of the importance of the speed of information or news where is facilitated by the digitalization of technology and algorithmic assistance, which is very crucial in making decisions that increase opportunities for profit and welfare.

Then, the trust factor becomes the main factor in influencing the mutual trust between the media and the audience so that it will raise hopes for a good relationship in the future. This trust process is generated from the process of digestion and filtering through critical thinking and comparisons to ensure the validity of information carried out by media consumers. Because media consumers are considered to have known which ones to trust or not and have understood to be able to sort out quality with the many choices of information that occur.

\section{REFERENCES}

Alsridi, H. (2018). Uses and Gratifications of Online News among Young Adults in Bahrain. Athens Journal of Mass Media and Communications, 4(1), 63-80. https://doi.org/10.30958/ajmmc.4.1.4

Aminuddin, A. T., \& Hasfi, N. (2020). Media Convergence of Central Java Daily Newspapers. Journal of Journalism Studies, 3(2), 137. https://doi.org/10.24198/jkj.v3i2.25070

Asyir, A. K., \& Nurbaya, S. (2019). Media Convergence and Mediamorfosis: The Digitalization Strategy of Moeslim Choice Magazine in the Work Base Transformation Process. JSJ: Journal of Journalism , 1(1), 52-67.

Creswell, J. W. (2014). Research Design: Qualitative, Quantitative, and Mixed Methods Approaches (Third Edit). SAGE Publications, Inc.

(2014). Research Design: Qualitative, Quantitative dan Mixed Methods Approaches. Yogyakarta: Pustaka Pelajar.

Dantes, Nyoman. (2012). Methodology. Yogyakarta: ANDI.

Edelman. (2019). Edelman Trust Barometer, accesing on https://www.edelman.com/sites/g/files/aatuss191/files/201902/2019_Edelman_Trust_Barometer_Global_Report.pdf

Gushevinalti, G., Suminar, P., \& Sunaryanto, H. (2020). Transformation of Communication Characteristics in Media Convergence Era. Bricolage: Journal of Master of Communication Science, 6(01), 083. https://doi.org/10.30813/bricolage.v6i01.2069 
Haqqu, R. (2020). Uses and Gratifications Test in the Intensity of Watching Talk Show Programs on Television. CoverAge: Journal of Strategic Communication, 10(2), 11-18. https://doi.org/10.35814/coverage.v10i2.1378 Jerry, Arvino. (2020). Interview Results with Vander Lesnussa on 25 July 2020. . (2020). Interview Results with Bambang Harymurti on 03 August 2020.

Kania, D., Agatha, N., Studi, P., Komunikasi, I., Bakrie, U., Bakrie, K. U., \& Colony, S. (2011). Online consumers and the application of uses and gratification theory. Journal Communication Spectrum, 1(2), 91-108.

Kriyantono, Rahmat. (2006). Practical Techniques for Communication Research. Jakarta : PT. Kencana Perdana

Kusuma, S. (2016). The Position of Printed Media in the Middle of Online Media Development in Indonesia. Unika Atma Jaya, 5, 56-71.

Musa, A. S., Azmi, M. N. L., \& Ismail, N. S. (2016). Exploring the Uses and Gratifications Theory in the Use of Social Media among the Students of Mass Communication in Nigeria. Malaysian Journal of Distance Education, 17(2), 83-95. https://doi.org/10.21315/mjde2015.17.2.6

Nurudin. (2013).Introduction of Mass Communication. Jakarta: PT Raja Grafindo Persada, 192.

Omar, B. (2014). Immediacy Gratification in Online News Consumption and its Relations to Surveillance, Orientation and Elaboration of News. Procedia - Social and Behavioral Sciences, 155(October), 405-410. https://doi.org/10.1016/j.sbspro.2014.10.313

Orihuela, J.L (2010). eCommunication: The 10 Paradigms of Media in the Digital Age. Towards New Media Paradigms: Content, Producers, Organisations and Audiences, Ediciones Eunate, Pamplona, 2004, pp. 129-135.

Respati, W. (2014). Mass Media Transformation Towards Information Society Era in Indonesia. Humaniora, 5(1), 39. https://doi.org/10.21512/humaniora.v5i1.2979

Ritchie, J., \& Lewis, J. (2003). Qualitative Research Practice: A Guide for Social Science Students and Researchers. SAGE Publications, Inc.

Rusadi, U. (2014). Consumption of News Across Conventional Mass Media and the Internet.

Journal of Research and Development of Communication and Informatics, 4(3), 173-187.

Sucahya, M. (2013). Communication Technology and Media. A journal of Communication, 1(2), 6-22. 